\title{
A Sociolinguistic Study of Choosing Names for Newborn Children in Jordan
}

\author{
Abeer Harb Al-Qawasmi ${ }^{1} \&$ Fawwaz Al-Abed Al-Haq ${ }^{1}$ \\ ${ }^{1}$ Department of English Language and Literature, Faculty of Arts, Yarmouk University, Irbid, Jordan \\ Correspondence: Abeer Harb Al-Qawasmi, Department of English Language and Literature, Faculty of Arts, \\ Yarmouk University, Irbid, Jordan. E-mail: abeerqawasmi26@yahoo.com or fawaz_m@yu.edu.jo
}

\author{
Received: November 24, 2015 Accepted: December 20, 2015 Online Published: January 31, 2016 \\ doi:10.5539/ijel.v6n1p177 URL: http://dx.doi.org/10.5539/ijel.v6n1p177
}

\begin{abstract}
This study aims at the study of newborn names in Jordan of a sociolinguistic perspective. This study tries to detect the difference in naming newborns in Jordan over the decades - from the seventies to 2015 due to the result of some factors that may have affected the Jordanian society, whether historical, religious and/or social. The data necessary to complete the study was obtained from the Civil Status Department and the Department of Statistics. The data obtained consisted of names of both sexes during the time period from the seventies until the early year of 2015, a random sample of personal names within the same family were also provided. The data was analyzed quantitatively. The study revealed that there is a clear change in the choice of newborn names-male and female-in Jordan, whether a change in sounds or in morphemes. In specific, names during the seventies were strongly linked to the culture and the values, religious or social, in which the people believed in. During the eighties and nineties, names were associated with certain social values, however, some names were shown to be affected by urbanization or modernization. And with the beginning of 2000 up to 2015, peoples directions towards naming newborns changed due to the advent of globalization, associating with development and urbanization, and moreover, the influence of different cultures on the community.
\end{abstract}

Keywords: naming practice, newborns, culture, sociolinguistic

\section{Introduction}

Naming is an essential and universal process, which people use to identify what surrounds them as a way of communication around the world. The word "name" has been defined as "a word or a group of words that suggest a certain entity whether it's a real or fictitious" (Encyclopaedia Britannica, 1926). The definition of the word "name" in Oxford Advanced Learner's Dictionary is "A word or set of words by which a person or thing is known, addressed, or referred to". Everything around us has to be identified by giving it a suitable name, to enable us to distinguish between these things. Many scholars and linguists have focused on the investigation of how names can reveal cultural insights, linguistic features, and the historical background of a society. For example, Lyons (1977) states that "the functional semantic of words has been seen as that of naming, as far as we can sign or indicate the history of linguistic estimation". According to Bean (1980, p. 306), states that there is a connection between a name and its bearer, which is created after choosing such a name. Also, Palmer (1981) shows that names are words used as a signifier and what objects referred to as a descriptor.

For human beings, a name is definitely the most important rights for human being that should carry an esthetical characteristic and have an acceptable meaning in society, so everyone should have a good name. The names which belong to humans are personal names, these are either person's name, family name or even person's nicknames. Mehrabian \& Piercy (1993) mention that the name gives an impression, either positive or negative such a (Whfa) وحشة, and has a corresponding impact in social interaction. Naming one's child with a pleasant name is one of the Islamic principles.

So, muslim parents are forced to choose a good name for their children. The Prophet Muhammad - peace and praise be upon him - said, "To whoever is born a boy and he names him Mohammad solely for the love of one and for the blessing name then both he and his son", because names affect the person's character (Raafat, 2004). Because personal names give the confidence to their bearers, that tell everybody all over the world who you are, and may tell the occasion and the origins behind choosing such names. 
Names are studied from a semantic point of view. Not all names have a meaning, when they have a meaning, they tend to have a positive impression (Zuraiq, 1999). As stated by Crystal, sound and meaning are hard to separate from each other (Crystal, 1995).

Socio-cultural background, attitudes, beliefs, and physical environment are non-linguistic factors, according to (Zuraiq, 1999). Every society has its own traditions when it comes to naming their newborns. When parents name their children, they tend to avoid names which may violate their social norms, and they seem to stick to certain names used within the same family, such as, naming their children after their grandparents, uncles, etc. Finally, as Rosenhouse (2002) states, naming is an act that reveals many factors, such as, traditions, hopes, feelings, fears, and daily events.

In Islam, the most beloved names to Allah are the following two: Abdullah and Abd-Ar-Rahman, as stated in the Hadith narrated that Ibn Umar (RA) said: Allah's Messenger (PBUH) said, "The most beloved of names to Allah, the Mighty and Sublime, are: Abdullah and Abd-Ar-Rahman." (Hadith No. 4949, Book of Etiquette, Sunan Abu Dawud, Vol. 5; Hadith No. 2833, Chapters on Manners, Jami' At-Tirmidhi, Vol. 5; Hadith No. 3728, Chapters on Etiquette, Sunan Ibn Majah, Vol. 5).

As Muslims, we must be careful enough to understand the process of naming a child. As a name for a child is sacred to him/her, so let it be good. When naming a child, the parents should take into consideration what the Glorious Qur'an and the Sunnah say.

The word "name" appears many times in The Glorious Qur'an. The first one when Allah taught Adam the names, which maybe the names of all creatures; humans, animals, trees, etc.

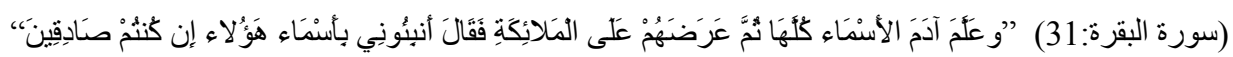

"And He taught Adam all the names, saying: Inform me of the names of these if you are truthful." (Al-Hayik, 1995).

The second time, when Imran's wife speaks to Allah, after giving birth;

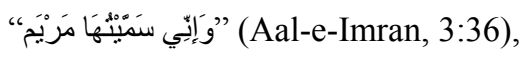

"I have - named her Mary" (Salahuddin, 1999).

In addition, when Allah brought to Zechariah a good news that he will have a boy whose name is John.

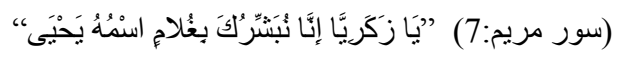

“O Zakariyya (Zachariah) verily, We give you glad tidings of a son, whose name will be Yahyâ (John)". (Al-Hilali \& Khan, 2004, p. 1427) (Maryam, 19: 7).

Akinnaso (1980) states that a personal name is a type of proper names. The process of personal naming has a main target, which is a system of symbols that reveal the identity of the personal names.

The child has been given his/her name after birth; the name may be related to particular social factors. For example; Yassin (1978) states, "the names in Kuwait may indicate the social situations". He also adds that the names may refer to historical events, for example, sea objects, plants, and precious metals.

According to our Arab societies, the names of new babies are chosen by the parents or by close relatives, and those names can reveal the circumstances behind choosing such a name (Bean, 1980).

In the USA, the parents' political ideology can be seen through their children's names, Pappas (2013) states that parents political status, liberal or conservative, can be seen through their choice of baby names. She elaborates by saying that the sounds of liberal and conservative names vary. Parents in liberal neighborhoods are more likely to choose softer, more feminine sounds, such as "L", and soft-A endings for their babies' names, such as Liam, Ely, Leila, Ella and Sophia while conservative parents tend to pick names with more masculine-sounding K's, B's, D's and T's, such as Kurt.

Jayaraman (2005) states that names in India are chosen depending on the religion and region which the person is from. Elaborating that personal or first names such as Rasheed, Krishna, \& David, and surnames such as Khan, Pradhan, and Das convey a person's religious. Therefore, it is possible to distinguish a Christian (David Das) from a Muslim (Rasheed Khan) from a Hindu (Krishna Pradhan). Furthermore, names in India also indicate whether the person comes from northern or southern India.

\section{Methods and Procedures}

The sample of this study consists of names of all registered newborn, male and female, children in Jordan during the period of the 70 s to the early year of 2015 . It also consists of names of newborn children within the same 
family, i.e., siblings, father/mother, grandfathers/mothers, uncles/aunts, etc. The selection of the families was random.

To fulfil the purpose of this study, the data which needed to conduct this study was collected by two methods. First, the researcher gathered data from the database at the Department of Statistics, listing the most frequently birth names by gender for the years 2009, 2010, 2011, 2012, and 2013.

Second, the researcher collected data from the Department of Civil Status, listing all personal names registered from the year 1980 to 2015. Furthermore, the researcher collected some additional data related to personal names within certain families.

The researcher applied the following methods in classifying and analysing the data related to the study of naming newborns in Jordan, in order to ease the understanding of how and why names are chosen.

1) The researcher classified the names of newborn into three eras; from seventies, eighties to nineties, 2000 to 2015.

2) The researcher analyzed how sound pattern of names has changed during time.

3) The researcher analyzed names chosen within the same family.

4) The researcher also showed the most frequent birth names, by gender, for the last 5 years after all the circumstances that have happened during these years.

\section{Results and Discussion}

For the purpose of the study, personal names were gathered from official documents provided by the database at the Department of Civil Status and from database at The Department of Statistics in Jordan.

Religion, naming after relatives, politics, naming according to surrounding environment, stressing certain times and places, and borrowing are the factors behind the sociolinguistic. So, studies of personal names have found that some personal names reveal at least one of these factors when the baby was born.

These names were categorized by the researcher into three main generation groups; The $70 \mathrm{~s}$, the period between the $80 \mathrm{~s}$ and $90 \mathrm{~s}$, and the period between the year 2000 and the 2015 . The researcher classified the names into these particular generations according to the similarity of the political, economical, social, and environmental events which have happened within each generation. Then, the identified names were compared in relation to the events, circumstances, and religion into which the children were born.

\subsection{The Choice of Newborn Names during the 70s}

Under this heading, based on the analysis of the gathered data, the researcher discusses the data concerning male newborn names and female newborn names that were chosen for children during the 70s.

This period of time witnessed many historical, political, religious and social events, which had not only affected the Jordanian society, but also the choice of male and female newborn names.

\subsubsection{In Relation to Historical Events}

Due to the strong relations between the Jordanian and the Palestinian societies, many events such as the displacement and expulsion of Palestinians from their homeland and the following the Battle of Karameh have had a great effect on Jordanian society, which helped in the appearance of new names carrying the meanings of struggle and Jehad. In Arabic, the word "jihād" is a noun meaning "to strive, to apply oneself, to struggle, to persevere". Terminological definition: If called often go out to fight the unbelievers, stubborn, and warriors, and apostates, and prostitutes, and towards them, and its purpose is to Glorified the word of Allah.

During the 70s, the names which identified by the researcher, were mostly Jehadi names for both females and males equally. The most frequent names for males are /nidha:1/ نضال (3.7\%), /jiha:d/ جهاد (2.9\%), /na:șr/ (2.8

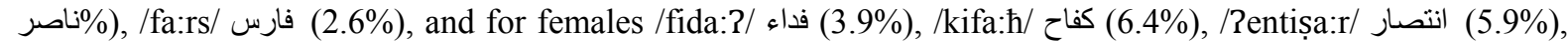
/najaa:h/ نجاح (4.1\%). The reason behind the choice of such names is considered to be the result of the events and circumstances which occurred before and during this period. Other historical events effecting the choice of newborn name in Jordan were the Six-Day War, known as النكسة, an-Naksah, when the Arab people tried to liberate Palestine, and The Yom Kippur War, يوم خيير, Ramadan War, or October War.

\subsubsection{In Relation to Religion}

In relation to religion, Jordan is an Arab Islamic country, so we talk about an Islamic society which follows the Islamic precepts in every work of life. Names, as mentioned before, are considered a great thing in Islam. In Islamic sociolinguistics, parents can name their male newborn after Prophets and messengers. The most common 


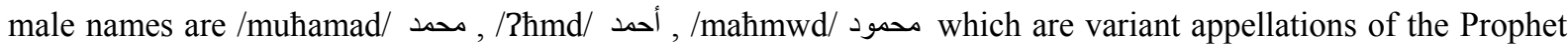
Muhammad's name, peace be upon him. Among the female newborns, the following religious names are also popular, /fa:țma/ فاطمة after the Prophet's daughter and//a:PJa/ عائثة after the Prophet's wife, though not as frequent as the male names. These common names which, carry the Arabic- Islamic features, whether for male newborns or female newbornsare still chosen till this period of time. Such as the female names /fa:tma/ فاطمة (12.5\%), /muћamad/ محمد (21.6\%), / عائشة (11.0\%). Table 1, shows the most frequents names chosen for this period of time.

Table 1. Names and frequency during the 70 s

\begin{tabular}{|c|c|c|c|c|c|c|}
\hline \multicolumn{2}{|c|}{ Female names } & \multirow{2}{*}{$\begin{array}{l}\text { Name Frequency } \\
724\end{array}$} & \multirow{2}{*}{$\begin{array}{l}\text { Rate \% } \\
6.4\end{array}$} & Male names & \multirow{2}{*}{$\begin{array}{l}\text { Name Frequency } \\
796\end{array}$} & \multirow{2}{*}{$\begin{array}{l}\text { Rate \% } \\
3.7\end{array}$} \\
\hline kifa:h & كفاح & & & نضال Nidha:1 & & \\
\hline fida? & فداء & 450 & 3.9 & yihad & 712 & 2.9 \\
\hline Renteșar & انتصار & 683 & 5.9 & na:șr & 604 & 2.8 \\
\hline nă̌a:ћ & ن نجاح & 468 & 4.1 & fa:rs & 563 & 2.6 \\
\hline $\mathrm{a}: 2 \int \mathrm{a}$ & عائشة & 401 & 3.5 & محد muhamad & 4514 & 21.6 \\
\hline fa:țma & فاطمة & 1431 & 12.6 & احمد ا & 2329 & 11 \\
\hline
\end{tabular}

Table 1 shows the percentage of names from the most 20 frequently used names by sex for this particular period. One of these names which is nidha:1 نضال consider a neutral name but unfortunately the percentage of this name for newborn female is unexcited.

During this period of time, there were appeared what is called Compound Names which are personal names consisting of more than one name. According to Abd-el-Jawad (1986), classified the compound names into three structural patterns. Firstly, / / bdd/ عبد servant of God (Allah) plus any of the attributes of God (Allah), of which there are potentially ninety-nine names, such as, /Sbd erahjm/عبد الرحيم. Secondly, a verbal noun expressing a positive attribute plus /adjn/ الدين religion, such as, /șala:hidjn/ صلاح الدين. Thirdly, a verbal noun expressing blessing and thanking of God (Allah) plus Allah, such as, /hamdullah/الحمداحس. But compound names, as meant here, are those which consist of the name of the Prophets Muhammad, peace be upon him, plus another common name, such as, /muћamad Sli:/ محمد علي, /muћamad hasan/ محمد حس and /muћamad jwsif/ محمد يوسف .

The political and atmospheric conditions and circumstances, which has happened in this period, impacted the society's daily life, thinking of wars, battles and Jihad. Consequently, the choice of newborn names for male and female were also affected.

\subsubsection{In Relation to Social Factors}

During this period, people lived a simple life, based on religious and social values, where there was little or in some cases outside influence. This can be shown by the social heritage of naming as sons were named after their grandfather and daughters after their grandmothers. The researcher explain that by consider this phenomenon as a tradition in the society which keep the name live not to die or the bearer of such a name is a distinguish person in the family.

\subsection{The Choice of Newborn Names during the Period between the 80s and the 90s}

As a result of the process of urbanization and modernization in all aspects of life, including naming, there is a strong tendency to abandon traditional, long, and compound names in favour of modern names which are described by many parents as being short, soft, and easy to write and pronounce, such as, /rana:/ ريم,/rjm and /nu:r/ نور.

Based on the analysis of gathered data, the researcher was able to identify the most frequent names chosen during the period between the $80 \mathrm{~s}$ and $90 \mathrm{~s}$.

\subsubsection{In Relation to Historical Events}

Due to the Iran-Iraq War, also known as the First Persian Gulf War, the names /ṣadam/صدام which is the name of the late president of Iraq, we noticed that in this period the frequent of chosen the name was 1056 out of 16342 and / Fudy/ عدي became the most frequently chosen names, as people became affected by the political events of these times, and this is due to the historical relations between the two counties, Jordan and Iraq.

\subsubsection{In Relation to Religion}

In relation to religion, the majority of Jordanian people are Muslims so they mainly choose Arabic-Islamic names. In this period of time, the names chosen still carried the Arabic- Islamic features, such as the female 


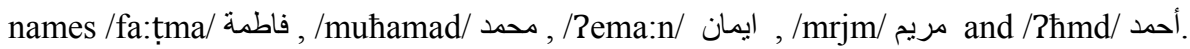

\subsubsection{In Relation to Social Factors}

During the $80 \mathrm{~s}$ and the $90 \mathrm{~s}$, the names identified by the researcher, were more authenticity such as the male

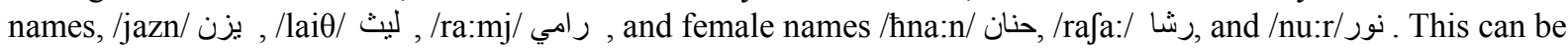
analyzed to indicate that the change in the daily lifestyle of the Jordanian people were affected by the appearance of satellite channels podcasting from all around the world, carrying with them not only new cultures but also new thoughts and ideologies, influencing the change in the choice of newborn names, for both male and female.

Also, in these periods of time, compound names were still used whether how Abd-el-Jawad classified them, mentioned and/or noticed above or as the researcher classified previously. The following table shows the most frequent names chosen for this period of time. The names were arranged in the table randomly.

Table 2. Names and frequency during the $80 \mathrm{~s}-90 \mathrm{~s}$

\begin{tabular}{|c|c|c|c|c|c|c|}
\hline \multicolumn{2}{|c|}{ Female names } & \multirow{2}{*}{$\begin{array}{l}\text { Name Frequency } \\
1753\end{array}$} & \multirow{2}{*}{$\begin{array}{l}\text { Rate \% } \\
9.0\end{array}$} & Male names & \multirow{2}{*}{$\begin{array}{l}\text { Name Frequency } \\
598\end{array}$} & \multirow{2}{*}{$\begin{array}{l}\text { Rate } \% \\
1.7\end{array}$} \\
\hline ћna: & حنان & & & Jazn يزن & & \\
\hline rafa: & ر تشا & 1445 & 7.4 & lai $\theta$ & 583 & 1.6 \\
\hline nu:r & نور & 1172 & 6.5 & ra:mj رامي & 627 & 1.8 \\
\hline Fa:țima & فاطمة & 1340 & 6.9 & صدام صدadam & 1056 & 3.1 \\
\hline Pema:n & ايمان & 1753 & 7.4 & عudy عuي & 1458 & 4.2 \\
\hline mrjm & ل مريم & 733 & 3.7 & محمد muhamad & 10126 & 29.4 \\
\hline \{a:? $\int \mathrm{a}$ & عائشة & 186 & 1 & احمد ا & 5947 & 17.3 \\
\hline
\end{tabular}

It is noticeable that female newborn and male newborn names were fitting, right, or true for persons during this period of time. The names are associated with the increase of modernization and urbanization of Jordanian people.

\subsection{The Choice of Newborn Names during the Period between the 2000 to the 2015}

\subsubsection{In Relation to Historical Events}

In the relation to the historical factors of this period, there were no noticeable changes in the choice of names for newborn males and females, even though these times were full of historical events, such as the Arab Spring, which mainly included all the neighboring countries.

However, in the early 2015, due to the recent "political" events in the Middle East, and moreover, after the brutal murder of the Jordanian pilot "Moath Al-Kasasbeh" معاذ الكساسبة, many Jordanian newborns have been given the name /mua:ð/ معاذ. This can be taken as a symbol of loyalty and unity of the Jordanian people.

\subsubsection{In Relation to Religion}

In relation to religion, the researcher has noticed that newborn male names remained to carry the Arab- Islamic feature with only a few foreign names, whereas, the Arab-Islamic features of female newborn names had decreased to the state where they are no longer used, or only a small percentage remains present. The researcher predict that the newborn female names which carry an Arabic-Islamic features will eventually disappear or at least become even less used in the future years to come.

\subsubsection{In Relation to Social Factors}

In the last two decades, Jordan, as many other communities in the Middle East, has witnessed and experienced tremendous, modernization, urbanization, globalization, and the Internet. Due to these revolutions, the world has become as some say "a small village", therefore, different societies and cultures have intertwined, borrowing and exchange not only terms and expressions, but also personal names. The consequence of this international communication is the appearance of new and foreign names bestowed upon male and female newborn names. So,

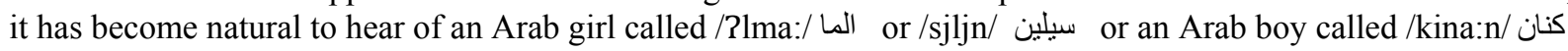
or / امير/. The choice of such names seems to be due to that foreign names are easy to pronounce, spell, and recall. Also, mass media during these particular periods play a significant role in developing this phenomenon, as Jordanian, like other nations, watch foreign programs and series on TV influencing lives.

Based on the data gathered, the researcher noticed, that during the year 2000 to the 2015, that there was a large increase in the number of newborns given foreign names, for instance, the female names / ايلين/2eljn,

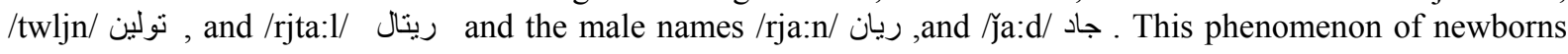


with foreign names is thought to have arisen due to the large number of Turkish and Western TV series and movies. A foreign newborn male name and newborn female name signify modernity, prestige and pride. To the opposite, this phenomenon of personal foreign naming could be a strategy of breaking away from traditional values. The following table shows the frequently chosen names for this period of time.

Table 3. Names and frequency during 2000-2014

\begin{tabular}{|c|c|c|c|c|c|c|c|}
\hline \multicolumn{2}{|l|}{$\begin{array}{l}\text { Female } \\
\text { names }\end{array}$} & \multirow{2}{*}{$\begin{array}{l}\text { Name Frequency } \\
893\end{array}$} & \multirow{2}{*}{$\begin{array}{l}\text { Rate \% } \\
1.1\end{array}$} & \multicolumn{2}{|c|}{ Male names } & \multirow{2}{*}{$\begin{array}{l}\text { Name Frequency } \\
1638\end{array}$} & \multirow{2}{*}{$\frac{\text { Rate } \%}{1.7}$} \\
\hline Peljn & إلين & & & rja:n & ريان & & \\
\hline lja:n & ل لبان & 2129 & 2.4 & ǰa:d & جاد ل & 534 & 0.6 \\
\hline rjta:1 & 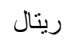 & 1128 & 1.3 & Pmjr & 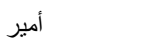 & 2488 & 2.7 \\
\hline mja:r & ميار & 1197 & 1.4 & Sbd alrћma: & عبد الرحمن ي & 3467 & 3.7 \\
\hline fa:țma & فاطمة & 432 & 0.5 & Muћamad & محمد & 12859 & 13.7 \\
\hline 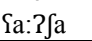 & ع عائشة & 112 & 0.1 & Pौmd & أحمد & 4781 & 4.9 \\
\hline
\end{tabular}

As shown in Table 3, these particular names were chosen, and arranged randomly, as they are the most frequently given birth names for both genders during this period as the result of the globalization and modernization.

Data analysis reveals a sex differentiation in naming patterns. The results seem to support one of the most important findings about sex-based language variation which emerged from sociolinguistic studies in the industrialized western world. These studies prove that women tend to be on the average to use more higher-status and prestigious linguistic change taking place in the direction of socially prestigious linguistic forms, and if new linguistic forms are introduced, women will be ahead of men (labov, 1972; Trudgill, 1974; Chambers \& Trudgill 1980).

Since a name is a symbol of identification, it can be also a symbol of social prestige. For females, a name is consider as a part of her beauty; therefore, parents choose an attractive name for their daughters, so they search carefully to find an attractive one which is beautiful both in sound and meaning. On the other hand, for males, a name is consider as a part of his personality; therefore, when parents choose a name for their son they select traditional and old names which once were very common. It could be said as in the Arab proverb "To every person his name is fortune" the Prophet, peace be upon him, changed the names of many of his companions to carry the best and noblest meanings, and he changed Amr Bin Hisham's nickname from Aba Alhikmato Abu Jahl for his insistence on infidelity.

During the study the researcher has noticed that compound names are no longer used as the use of these kinds of names have been discouraged by the government in this period of time.

Table 4. Arabic- Islamic names

\begin{tabular}{|c|c|c|c|c|}
\hline \multirow{2}{*}{ Period } & \multicolumn{2}{|c|}{ Female name } & \multicolumn{2}{|c|}{ Male names } \\
\hline & Fa:țma & 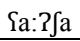 & Muћamad & ?ћmd \\
\hline $70 \mathrm{~s}$ & 1431 & 401 & 5559 & 2575 \\
\hline $80 \mathrm{~s}-90 \mathrm{~s}$ & 1318 & 186 & 8813 & 4707 \\
\hline $2000-2015$ & 432 & 112 & 15642 & 4781 \\
\hline
\end{tabular}

As shown in Table 4, the main difference between male and female is the disappearance of religious female names such as /fa:țma/ فاطمة the frequency of the name in the 2015 compared to the previous generations. The researcher believes that in the forthcoming days with the rapid increase in the use of English and foreign names this will further exist to effect the choice of names as, the newborn male names carrying an Arabic-Islamic features and which indicate qualities and attribution of manhood, courage, nobility and generosity will die out as well as newborn female names which have started to die since the beginning of the process of modernization and globalization.

These particular names, as shown in Table 4 have been chosen for their religious significance, as these names will never die out or become unused. Religious feelings reflect on the lifestyle, pattern of thinking, and consequently the linguistic behavior including naming. As noticed, people during the seventies, people refused the influence of the Western culture and decided to keep the choice of Arab Islamic prestigious names but with 
the passage of time and with the emergence of urbanization or modernization and technology people seemed to accept the entry and the influence of the Western culture and then the acceptance of its effect, also in the choice of names.

Throughout this study, the researcher noticed that the first two generations the parents derive the names of females from the names of males, such as the female name /Ja:dja/ شادية from the male name//a:dj/ شادي /fa:dja/

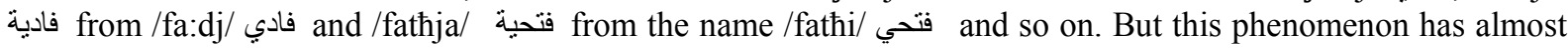
disappeared nowadays.

\subsection{Phonetic Change of Sound Pattern Personal Names through Times}

While analysing the gathered data, the researcher observed that there are a number of phonetic changes in sound pattern of personal names, especially in female names.

The data shows that the phonetic sounds of personal names have changed throughout time. In comparing and contrasting personal names from the 70s with those from the 2014-2015, we can see that in the past names used to be heavy and consist of dark sounds, such as the dark /1/ sound. As in, the female names /xawla/ خولة , /nawa:1/ خلود /

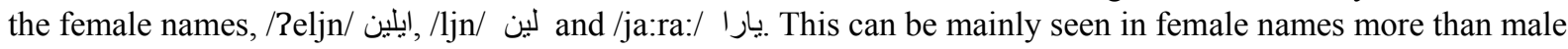
names. This phenomenon formed maybe as a result of the political chaos surrounding the community, affecting clearly and concretely on the choice of names, making it possible to say that the political chaos formed a mess in the selected names.

\subsection{How the Names are Chosen within the Same Family}

As another interesting fact about naming newborns, throughout the study the researcher observed that there was, in some families, a trend of choosing similar names for siblings that making their family distinguished from others, many strategies may be used: The first one, is by the use of similar sound for all children, such as /su:ha/

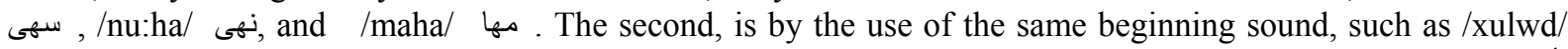

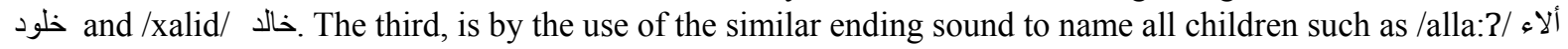

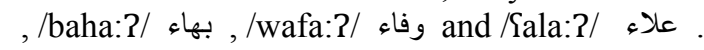

These strategies can be visible in many families in Jordan, a possible justification for the use of these strategies is that it makes it more easier for the parents to call their children, as some find it joyful for if they call one child, all may answer as they all have the same sounds in their names. Another justification is that some parents find it more musical to name all their children using the same rhythm. And we can say that parents subconsciously substitute similar sounding sibling names more often than dissimilar names.

\section{Summary and Conclusion}

This present study, which arose from a sociolinguistic interest, is an identification of how the choice of names for newborn children in Jordan has changed throughout the eras, as documented in the official database at the Department of civil status and by the Department of Statistics. It also aimed at identifying the reasons behind the difference in choice of names given to newborn children in Jordan, in relation to the social, religious, and historical events, which occurred during the eras in question.

The researcher came up with the following conclusions. Generally, the change in the choice of names for newborns is quite evident. Especially, in relation to the events, circumstances, and political conditions affecting the Jordanian society during the times, this can be most evident during the 1970s all through to the early year of 2015. With the evidence of the choice of mostly "Jedahi" names in the 70s, and the choice of naming newborns after well known politicians during the $80 \mathrm{~s}$ to $90 \mathrm{~s}$, due to the wars and political events which happened during this decade, as mentioned previously. Such trend seemed to fade during the years 2000 to 2014, despite the political events present at such time, the Arab Spring. However, at the beginning of the year 2015, it was evident once more with the obvious increase in the choice of the name /mua:ð/ sef after the Martyr Jordanian pilot "Moath Al-kasasbeh".

The political and atmospheric conditions and circumstances, which have happened during these periods of time, have had a great impact on the society's daily life, resulting in their thinking of wars, battles and Jihad. Consequently, the choice of newborn names for male and female were also affected.

With regard to religion, the findings show that the choice of Arabic-Islamic names is evident during the 70s, for both males and females, as newborns were named after Prophets, messengers, and famous religious figures. During the 80 s to 90 s, male's names still seemed to carry Arabic-Islamic features, whereas, a minor change in the choice of female names was visible, as they became lighter and more modern. This became more evident 
during the years 2000 to 2015, as the Arabic-Islamic features of female names decreased and the appearance of more names carrying no religious features what so ever. It was predicted that the choice of female Arabic-Islamic names will eventually become rare and therefore less used in the future years to come.

Religious feelings reflect on the lifestyle, pattern of thinking, and consequently the linguistic behavior including naming. As noticed, people during the 70s, refused the influence of the western culture and decided to keep the choice of Arabic-Islamic prestigious names. On the other hand, as time proceeded with the emergence of urbanization/modernization and technical development, people seemed to accept the entry and the influence of the Western culture and then the acceptance of its effect, not only on their lifestyle, but also on their choice of names.

With regard to the social features affecting the choice of names for newborns in Jordan, it was quite evident during the 70s that family values played a great role in the choice of names, as children were named after either their grandfather or grandmother or even after an uncle or an aunt. This comes to show how close and intermit families were during this time. When coming to the $80 \mathrm{~s}$ and $90 \mathrm{~s}$, it was evident that the choice of names for newborns was affected by technical development, moreover, the home invasion by satellite channels resulted in the enlightenment of the Jordanian people to different cultures and ideologies, and even more, resulting in the choice of foreign and more modern names for their newborns. During the 2000 to 2015, a large increase in the number of foreign names given to newborns, especially females was evidently visible. This is mostly due to the Internet and the increase of Turkish and Western television series, as people have become influenced by these TV programmes that they began naming their children after certain characters; even though these names are of Arabic origin, they have not been used in the same way as after the appearance of dubbed TV series. This can be seen as a strategy for steering away from traditional values towards modernization.

Accordingly, for a person, his/her name becomes the property of his/her personality. Like every aspect of society, the name, which is a symbolic system of identification, is usually "historically constructed, socially maintained, and based on shared assumption of a particular community" (Akinnaso, 1980, p. 227). In the present days, in Jordan, the bestowal of a newborn's name is the parents' duty.

Since a name is a symbol of identification, it can be also a symbol of social prestige. For females, a name is consider as a part of her beauty; therefore, parents choose an attractive name for their daughters, so they search carefully to find an attractive one which is beautiful both in sound and meaning. On the other hand, for males, a name is consider as a part of his personality; therefore, when parents choose a name for their son they select traditional and old names which once were very common.

Furthermore, while reviewing the gathered data, more evidence of change in the choice of newborn names surfaced, either being in the structure, meaning and/or gender.

Firstly, it was noticed that during the 70 s to the late 80 s some female names were derived from names that of

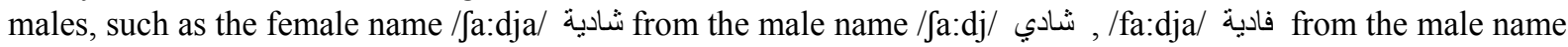

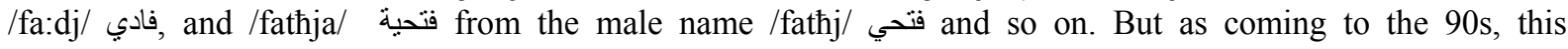
phenomenon has almost disappear.

Secondly, the phonetic differentiation of personal names throughout the eras; It was observed that there is a number of phonetic changes in the sounds of personal names, especially in female names.

Findings show that the phonetic sounds of personal names have changed throughout time. In comparing personal names from the 70s with those from the 2014-2015, in the past names used to be heavy and consist of dark

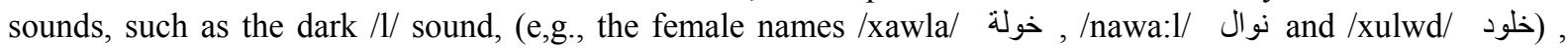
whereas, in 2014-2015 names seem to be more lighter, rhythmic, shorter and easier to pronounce and spell, such

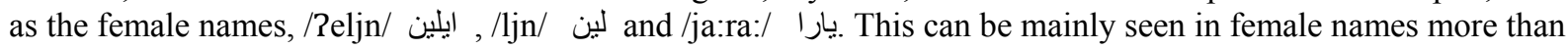
in male names.

Thirdly, naming newborns within the same family, i.e., brothers and sisters. As another interesting fact about naming newborns, it was observed that in some families there was a trend of choosing similar names for siblings. In order to make their family distinguished from others.

A possible justification for the use of this is that it makes it easier for parents to call their children, as some find it joyful as if they call one child, all the other children may answer as they all have the same sounds in their names, making it hard to distinguish which name is being call. Another justification is that some parents find it more musical to name all their children using the same rhythm ending. And it can be said that parents subconsciously substitute similar sounding sibling names more often than dissimilar names.

Fourthly, during the 70s there were as called "Compound Names" which are personal names consisting of more 
than one name. According to Abd-el-Jawad (1986), classified the compound names into three structural patterns:

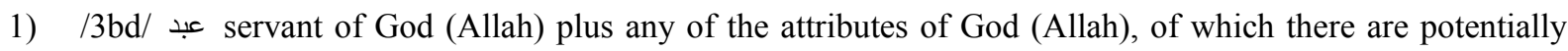
ninety-nine names, such as, /Sbd erahjm/عبدالرحيم.

2) a verbal noun expressing a positive attribute plus /adjn/الدين religion, such as, /ṣala:hidjn/ صلاح الدين.

3) a verbal noun expressing blessing and thanking of God (Allah) plus Allah, such as, /hamdu:llah/الحمدلن/2.

But compound names, as meant here, are those which consist of the name of the Prophets Muhammad, peace be upon him, plus another common name, such as, /muhamad flj/ محمد علي, /muhamad hasan/ محمد حسن and /Muћamad jwsif/ محمد يوسف. Mainly the Jordanian government has discouraged the use of such compound names, as much confusion occurs in result of such names. As it is hard to distinguish if the second name is part of a compound personal name or that if it is the person's father's name.

Finally, as a general aspect noticed to be present in all periods in question, that there are some female names written/spelled in more than one way, such as the name/ra:nja/ (رانيا ، رانيه ، رانية) which is written with three ending variations "८" or "¿" or "L", all carrying the same meaning and pronunciation, but different spelling. This phenomenon may be related to the non-standardized spelling of such names by the community.

In conclusion, personal names are useful tools for reference as they provide information on various events in the life of an individual, the family or the society.

\section{References}

Abd-el-Jawad, H. (1986). A linguistic and sociocultural study of personal names in Jordan. Anthropological Linguistics, 28(1), 80-94.

Adjah, O. A. (2011). What Is in a Name? Ghanaian Personal Names as Information Sources. African Research \& Documentation, (117).

Agyekum, K. (2006). The Sociolinguistic of Akan Personal Names. Nordic Journal of African Studies, 15(2), 206-235.

Akinnaso, F. (1980). The Sociolinguistic Basic of Yoruba Personal Names. Anthropological Linguistics, 22(7), 275-305.

Alokaily, J. (2005). A Semantico-cultural Study of Place Names in Jordan. MA Thesis, Yarmouk University, Irbid, Jordan.

Al-Shahi, A. (1988). Some Personal Names and Nicknames among the Rivera in People of Northern Sudan. Journal of the Anthropological Society of Oxford, 19(2), 131-139.

Al-Tahat, A. (2014). A Socio-Semantic Study of Family Names in Jordan. MA Thesis, Yarmouk University, Irbid, Jordan.

Al-Zumor, A. W. (2009). A Socio-Cultural and Linguistic Analysis of Yemeni Arabic Personal Names. GEMA Online Journal of Language Studies, 15(2).

Babycenter.com. (2014). Top 10 baby names around the world 2014. BabyCenter, L. L. C.

Bader, Y., \& Salih, M. (1997). A Diachronic Analysis of Personal Names in Jordan. Interface: Journal of Applied Linguistics, 12(1), 3-13.

Crystal, D. (1995). Phoneasthetically Speaking. English Today, 11(2), 8-12. http://dx.doi.org/10.1017/S026607840000818X

Cutler, A. (1990). Elizabeth and John: sound pattern of men's and women's names. Journal of Linguistics, 26(2), 471-482. http://dx.doi.org/10.1017/S0022226700014754

Encyclopedia Britannica. (1926). London: The Encyclopedia Britannica Inc.

Jayaraman, R. (2005). Personal Identity in a Globalized World: Cultural Roots of Hindu Personal Names and Surnames. The Journal of Popular Culture, 38(3). http://dx.doi.org/10.1111/j.0022-3840.2005.00124.x

Kimenyi, A. (1978). Aspect of Naming in Kinyarwanda. Anthropological linguistics, 20(1), 258-271.

Kwinika, S. (2010). South Africa World Cup baby names: Moms choose Fifa, Bafana, and Soccer City. Christian Science Monitor, 08827729, 6/22/2010.

Liseli, A., \& Fitzpatrick, B. A. (2012). African Names and Naming Practice. The Impact Slavery and European Domination Had on the African Psyche Identity and Protest. MA Thesis, Ohio State University, USA. 
Mehrabian, A., \& Marlena, P. (1993). Differences in Positive and Negative Connotations of Nicknames and $\begin{array}{lllll}\text { Given Names. Journal of Social Psychology, 133(5), 737. } & \end{array}$ http://dx.doi.org/10.1080/00224545.1993.9713930

Mphande, L. (2006). Naming and Linguistic Africanism in African American Cultural. Ohio State University.

Pappas, S. (2013). Baby Names Reveal Parents' Political Ideology. Live Science Contributor.

Salahuddin, A. (1999). A Dictionary of Muslim Names. London, United Kingdom.

Salih, M., \& Bader, Y. (1999). Personal Names of Jordanian Arab Christians: A Sociology of Language. International Journal of the Sociology of Language, 140(1), 29-44.

Trends in Naming Babies. (2001). The Christian Science Monitor, 93(32), p. 14.

Wardat, M. (1997). Nicknaming in Jordanian Arabic: A Sociolinguistic Perspective. Interface: Journal of Applied Linguistics, 12(1), 45-58.

Yassin, M. (1978). Personal Names of Address in Kuwaiti Arabic. Anthropological Linguistics, 20(2), 53-63.

Zuraiq, M. (1999). Linguistic and non-Linguistic Factors Influencing Name Giving in Jordan. MA Thesis, Yarmouk University, Irbid, Jordan.

\section{Copyrights}

Copyright for this article is retained by the author(s), with first publication rights granted to the journal.

This is an open-access article distributed under the terms and conditions of the Creative Commons Attribution license (http://creativecommons.org/licenses/by/3.0/). 